\title{
Annie Brudo, Les pièces inachevées du «Théâtre» de Balzac
}

\section{Marco Stupazzoni}

\section{Q OpenEdition}

1 Journals

\section{Edizione digitale}

URL: http://journals.openedition.org/studifrancesi/33392

DOI: 10.4000/studifrancesi.33392

ISSN: 2421-5856

\section{Editore}

Rosenberg \& Sellier

\section{Edizione cartacea}

Data di pubblicazione: 1 décembre 2005

Paginazione: 659-660

ISSN: 0039-2944

Notizia bibliografica digitale

Marco Stupazzoni, «Annie Brudo, Les pièces inachevées du «Théâtre» de Balzac», Studi Francesi [Online] 147 (XLX | III) | 2005, online dal 30 novembre 2015, consultato il 19 avril 2021. URL: http:// journals.openedition.org/studifrancesi/33392 ; DOI: https://doi.org/10.4000/studifrancesi.33392

Questo documento è stato generato automaticamente il 19 avril 2021.

\section{(c) (i) (9)}

Studi Francesi è distribuita con Licenza Creative Commons Attribuzione - Non commerciale - Non opere derivate 4.0 Internazionale. 


\title{
Annie Brudo, Les pièces inachevées du «Théâtre» de Balzac
}

\author{
Marco Stupazzoni
}

\section{NOTIZIA}

ANNIE BRUDO, Les pièces inachevées du «Théâtre» de Balzac, in AA.VV., Lingua, cultura e testo. Miscellanea di studi francesi in onore di Sergio Cigada, a cura di Enrica GALAzZI e Giuseppe BERNARDELLI, Milano, Vita e Pensiero, 2003, Volume II - Tomo 1, pp. 139-152.

1 Nell'ambito della frenetica attività di scrittura balzachiana, il ricco e variegato mosaico delle "oeuvres avortées" costituisce una testimonianza esemplare della intensità progettuale e della fecondità artistica del romanziere francese. Accanto alle opere narrative in cantiere, più volte annunciate e mai portate a definitivo compimento, merita senza dubbio una attenzione particolare l'insieme delle cosiddette "pièces avortées", vale a dire quelle opere teatrali progettate e mai concluse che attraversano l'intero percorso letterario di Balzac dal 1820 al 1848. Queste "pièces inachevées et quasiment ignorées, osserva A. Brudo, /.../ témoignent non seulement de la prodigieuse fécondité et de l'intérêt permanent que Balzac cultiva pour le théâtre, mais elles nous renseignent surtout sur la création et sur l'élaboration de son œuvre colossale dont le théâtre constitue /.../ une étape fondamentale, voire la source même de son inspiration» (p. 140). In queste opere, Balzac non disdegna alcun genere e sviluppa una varietà di tematiche che risentono certo dell'influenza di autori stranieri quali Shakespeare, Machiavelli, Byron, Scott o Cooper, ma che già assumono una peculiarità storico-letteraria propria. Balzac, puntualizza bene l'A., intende fermamente contribuire «au renouvellement du théâtre comme il avait contribué à celui du roman» (p. 149): la filiazione tra teatro e romanzo si pone quindi come un principio-cardine della poetica letteraria balzachiana $\mathrm{e}$, da questo punto di vista, è possibile condividere con l'A. l'assunto secondo cui «l'inachèvement, chez Balzac, est rarement l'indice d'un 
échec, d'un ratage; il s'inscrit plutôt dans le processus créatif, dans la question de la génétique de l'oeuvre» (p. 151). 